\title{
Endoscopic observations of invertebrate larval substratum exploration and settlement
}

\author{
Linda J. Walters*, Gilles Miron**, Edwin Bourget \\ GIROQ, Département de Biologie, Université Laval, Québec, Québec G1K 7P4, Canada
}

\begin{abstract}
In the marine environment, competent larvae of sessile invertebrates are influenced by water flow and a variety of biological, chemical and physical cues. Most research has focused on how these biotic and abiotic factors influence where individual larvae ultimately settle. Much less is known about post-contact exploration prior to metamorphosis. This is, in part, due to limitations associated with directly observing small larvae $(100$ to $500 \mu \mathrm{m})$ in flowing seawater. A study was conducted in Beaufort, North Carolina, USA to understand how larvae of the barnacle Balanus amphitrite and the bryozoan Bugula neritina respond to a variety of flow rates $\left(0,1.3,6.1\right.$ and $\left.8.3 \mathrm{~cm} \mathrm{~s}^{-1}\right)$ and surface types (clean, biofilmed, 1 and $2 \mathrm{wk}$ fouled). Larval behavior was studied by means of endoscopy in a runningseawater chamber. Larval movements were observed at 30 frames $^{-1}$ for individuals that remained in contact with surfaces from $<1.0 \mathrm{~s}$ to $44.5 \mathrm{~min}$. Both flow rate and surface type significantly influenced the behavior of the species examined, although larvae of $B$ amphitrite and $B$. neritina often responded very differently to the same treatment conditions. Larvae of $B$. amphitrite explored more surface area (fractal dimensions) in moving water than in still water, but flow did not influence the direction of travel. Mean exploration rate of $B$. amphitrite did not vary among treatments and ranged from 0.16 to $0.21 \mathrm{~mm} \mathrm{~s}^{-1}$ More cyprid larvae explored surfaces with macrofouling and spent significantly longer times on these surfaces than on clean ones. In still water, larvae of $B$. neritina repeatedly contacted, explored and swam away from the test surfaces. In contrast, in flow, larvae of $B$. neritina never swam away from any surface after contact was made. Individuals of $B$. neritina crawled directly upstream on clean and biofilmed surfaces at all flow rates unless individuals encountered filamentous structures (biofilmed surfaces only). When this happened, larvae of $B$. neritina frequently remained attached to filaments as the filaments moved with the flow. These larvae were then either dislodged or immediately resumed crawling upstream upon contact with the plate surface. A limited number of larvae of both species settled during our observations $(15 \%$ B. amphitrite, $18 \% B$. neritina $)$. Settlement of $B$. amphitrite was not correlated with flow rate or surface type; larvae of $B$. neritina settled only on 2 wk fouled surfaces
\end{abstract}

KEY WORDS: Balanus amphitrite Biological fouling - Bugula neritina . Endoscope Fouling community - Fractals Larval ecology

\section{INTRODUCTION}

Recruitment of many sessile invertebrates is influenced by water flow (e.g. Wethey 1986, Butman 1987, Havenhand \& Svane 1991, Harvey et al. 1995, Walters et al. 1997) and a variety of biological, chemical and physical factors (reviews: Meadows \& Camp-

Present addresses:

- Department of Biology, University of Central Florida, Orlando, Florida 32816.USA.E-mail: ljwalter@pegasus.cc.ucf.edu

- Département de Biologie, Université de Moncton, Moncton,

Nouveau-Brunswick, E1A 3E9, Canada bell 1972, Crisp 1976, 1984, Pawlik 1992). Most research has focused on the importance of these biotic and abiotic factors on the permanent attachment locations of individuals using indirect observations or approaches such as relative abundances of settled larvae (e.g. Sutherland \& Karlson 1977. LeTourneux \& Bourget 1988, Mullineaux \& Garland 1993, Hills \& Thomason 1996, 1998, Walters \& Wethey 1996). Much less is known about how these factors influence the behavior of a larva from the moment an individual contacts a surface through the time metamorphosis occurs or the larva leaves the surface. 
A larva may passively encounter or actively choose its initial contact location. Regardless of how a surface is contacted, larval behavior can influence final attachment location (Walters 1992a). Several post-contact exploratory behaviors are possible. The larva may actively choose to attach to the initial contact location. Alternatively, the larva may reject the initial contact location and leave by crawling or returning to the water column. Large distances may be covered if the individual re-enters the water column; relatively less area can be covered if the larva explores the surface by crawling. Both modes of exploration may also be combined. If there is no post-contact decision regarding settlement location, then local hydrodynamics will determine attachment locations.

The limited amount of research on the exploratory behavior of sessile marine invertebrate larvae under field conditions is due largely to the difficulties involved in following the movements of individuals in the 50 to $500 \mu \mathrm{m}$ range in flowing seawater, especially on fouled surfaces. Larval surface contact and details of subsequent exploration prior to permanent attachment and metamorphosis have only been described in detail in a few species from still-water laboratory observations (e.g. barnacle: Crisp \& Austen 1960; polychaete tubeworm: Wisely 1960; bryozoans: Ryland 1974, Woollacott 1984; oysters: Cranfield 1973). These authors provided evidence for larval exploration in still water by following the paths of individuals from contact to settlement or surface rejection. These results are very informative, but ignore the potentially significant role water flow plays in exploration. In controlled flow in flumes, other authors have demonstrated the interaction of flow and larval behavior by documenting active rejection of specific surfaces (e.g. Mullineaux \& Butman 1991, Pawlik et al. 1991). For example, Pawlik et al. (1991) observed that in $15 \mathrm{~cm} \mathrm{~s}^{-1}$ flows, larvae of Phragmatopoma lapidosa californica swam straight to the bottom and tumbled over the surface until an inductive chemical cue was encountered. At this time, the larva metamorphosed. However, at $5 \mathrm{~cm} \mathrm{~s}^{-1}$ flows, many larvae remained near the water surface or swam in meandering spirals in the upper water column, potentially actively avoiding settlement (Pawlik et al. 1991).

In field trials, inferences to post-contact larval exploration have also been made. Walters (1992a) compared the initial contact locations of the barnacle Balanus amphitrite and the bryozoan Bugula neritina with the metamorphosis locations of these species and found both species settled more frequently around the bases of bumps than would be predicted from the distribution of initial surface contacts. Neither differential mortality nor passive erosion of larvae explained these results; exploration of the surface provided the best explanation. Similar inferences about exploration have been made for a variety of invertebrate larvae, including the hydrozoans Tubularia crocea (Lemire \& Bourget 1996, Bourget \& Harvey 1998) and I. larynx (Mullineaux \& Garland 1993, Bourget \& Harvey 1998), the scallop Placopecten magellanicus (Bourget \& Harvey 1998), the bryozoans Schizoporella unicornis (Mullineaux \& Garland 1993) and Flustrella hispida (Bourget \& Harvey 1998), the annelid Spirorbis borealis (Bourget \& Harvey 1998) and the barnacle Balanus crenatus (Miron et al. 1996a). Additionally, field data from competition (e.g. Grosberg 1981) and predation trials (e.g. Johnson \& Strathmann 1989) strongly suggest that larval searching behavior does occur for sessile invertebrates after a hard surface is encountered.

Advanced technologies are now making it possible to directly observe larval exploration in flow on fouled surfaces. Endoscopy, combined with video recording and image analysis, allows direct observation of behavioral events, as well as convenient post-observational analysis and documentation (Ward et al. 1991). Endoscopes are impervious to seawater, have a large depth of field that can be kept at a distance from the organisms thus minimizing turbulence, and are designed to observe particles in the size range of larvae $(50$ to $500 \mu \mathrm{m})$. Despite these advantages, endoscopic observations have not previously been used to study larval settlement processes.

In this study, we used endoscopes to observe, record and analyze the larval behavior of 2 ubiquitous, sessile marine invertebrates, the barnacle Balanus amphitrite (Darwin) and the bryozoan Bugula neritina (Linnaeus), while settling on hard surfaces at various flow rates. $B$. amphitrite and $B$. neritina are common members of fouling communities in tropical and warm temperate waters around the globe. Cypris larvae of $B$. amphitrite are $356.7 \pm 9.3 \mu \mathrm{m}$ (mean $\pm \mathrm{SE}, \mathrm{N}=30$ ) in length and $159.4 \pm 3.2 \mu \mathrm{m}$ wide cigar-shaped individuals (Walters $\&$ Wethey 1996). The anterior portion of the cyprid encloses the antennules with their attachment disks used for crawling over surfaces in still water; the posterior encloses the thoracic appendages used in swimming (Crisp 1976). The antennules can adhere firmly to the surface so that larvae are not easily dislodged (Yule \& Walker 1984, 1985, Eckman et al. 1990). Cyprids have no functional gut; they can survive for approximately $2 \mathrm{wk}$ on stored materials, although both settlement specificity and settlement ability diminish over time (Rittschof et al. 1984, Satuito et al. 1996).

Coronate larvae of Bugula neritina measure $166.7 \pm$ $3.1 \mu \mathrm{m}$ in diameter, are covered by cilia, and are brooded singly by maternal zooids in ovicells until competent to settle (Keough 1989, Walters \& Wethey 1996). After release, larvae are non-feeding and swim 
for a few hours (Woollacott \& Zimmer 1971). In still water, when the swimming phase is complete, larvae become photonegative and geopositive and begin to explore surfaces (Lynch 1947, Nellis \& Bourget 1996). Individuals swim in counter-clockwise circles of decreasing circumference over the surface, 'testing' the substrate with bundles of cilia (Woollacott \& Zimmer 1971). During this phase, larvae frequently attach temporarily to a surface, but may break this bond and continue exploring (Woollacott 1984). Once metamorphosis has begun, larvae transform into the basic body plan of the sessile ancestrula within 20 min (Woollacott \& Zimmer 1971).

Larvae of both Balanus amphitrite and Bugula neritina settle in response to a variety of environmental factors. Both settle almost exclusively in small crevices, the sites that provide them with the best refuge (Walters \& Wethey 1996). Both species readily settle on clean surfaces (Roberts et al. 1991); specific bacterial strains may however influence attachment ( $B$. amphitrite: Maki et al. 1988; B. neritina: Mihm et al. 1981, Maki et al. 1989). Larvae of B. amphitrite are gregarious, settling in high numbers on surfaces treated with conspecific arthropodin or previously colonized by conspecifics or congeners (e.g. Crisp 1990); there is no evidence of gregariousness in settling larvae of $B$. neritina (Walters 1992b). Exogenous cues from other organisms may be effective at inhibiting the settlement of one or both species (e.g. Rittschof et al. 1988, Walters et al. 1996). To understand the relative importance of flow rate, microbial films and previously settled organisms on the benthic post-contact behavior of larvae of $B$, amphitrite and $B$. neritina, we observed and recorded individual larvae with an endoscope on surfaces colonized to different degrees and exposed to different flow rates.

\section{MATERIALS AND METHODS}

Collection of larvae. Larvae of the bryozoan Bugula neritina were obtained from brooding adult colonies collected in the morning of each trial day underneath a floating dock at the Duke University Marine Laboratory in Beaufort, North Carolina $\left(34^{\circ} 43^{\prime} 03^{\prime \prime} \mathrm{N}, 76^{\circ} 40^{\prime}\right.$ $\left.18^{\prime \prime} \mathrm{W}\right)$. In the laboratory, colonies were placed in a small tank filled with seawater under bright light to induce larval release (Lynch 1947). Within $10 \mathrm{~min}$ of release, actively swimming larvae were collected from the stock tank with a pipette and used in trials.

Cypris larvae of the barnacle Balanus amphitrite were obtained from a stock of adult individuals maintained at the Duke University Marine Laboratory and reared in batch culture on Skeletonema costatum as described by Rittschof et al. $(1984,1992)$. The cyprid stage was reached $4 \mathrm{~d}$ after hatching. Cyprids were stored in the dark at $4^{\circ} \mathrm{C}$. At this temperature, cyprids are inactive and do not settle (Rittschof et al. 1984). Only $3 \mathrm{~d}$ old cyprids were used in our trials, as settlement is greatest for cyprids of $B$. amphitrite in this age group (Satuito et al. 1996). A new batch of larvae was produced every $7 \mathrm{~d}$. Collection of larvae and all experiments were carried out during September and October of 1995.

Experimental procedures. To examine how surface composition influenced the exploratory behavior of larvae of Bugula neritina and Balanus amphitrite, $8.5 \times$ $8.5 \times 0.1 \mathrm{~cm}$ settlement surfaces were cut from darkgreen plastic. Reference grids were marked on each plate at $0.5 \mathrm{~cm}$ intervals with an indelible marker. Thus, individual grids measured $0.25 \mathrm{~cm}^{2}$. Four surface treatments were used: clean, biofilmed, 1 and $2 \mathrm{wk}$ fouled. The clean treatment corresponded to surfaces which had previously been aged in flowing seawater in the laboratory for $1 \mathrm{wk}$, but were cleaned with paper toweling to remove the microbial film before use in our trials. The biofilm treatment corresponded to surfaces that were soaked in the laboratory in running seawater for 1 wk prior to the start of the trials, but had no macro-organisms present on their surfaces. Fouled treatments corresponded to plates that were attached face-down with stainless steel screws to a Vexar ${ }^{\otimes}$ mesh and PVC pipe frame placed approximately $20 \mathrm{~cm}$ under a floating dock and colonized in the field by the natural fouling community for 1 or 2 wk. During our experiments, fouling organisms recruiting on test surfaces included $B$. amphitrite, $B$. neritina, the arborescent hydroids Tubularia crocea and Eudendrium carneum, the encrusting bryozoans Schizoporella errata and Membranipora tenuis, the serpulid polychaete Hydroides dianthus, the ascidian Styela plicata, spirobid worms and mud-tubes of amphipods. After $1 \mathrm{wk}, 15.0 \pm 2.5 \%$ (mean $\pm \mathrm{SE}, \mathrm{N}=15$ ) of each surface was covered by fouling organisms; after $2 \mathrm{wk} 85.0 \pm$ $5.0 \%$ of each surface was covered. Maximum height of arborescent species was $3.5 \mathrm{~mm}$ after $1 \mathrm{wk}$ and $8.0 \mathrm{~mm}$ after 2 wk. Current speeds directly beneath the surface at this site ranged from 0 to $15 \mathrm{~cm} \mathrm{~s}^{-1}$ (Culliney 1969).

In the laboratory, experimental surfaces were placed, one at a time, in a plastic flow chamber (13.5 cm length $\times 13.5 \mathrm{~cm}$ width $\times 4.0 \mathrm{~cm}$ height) securely affixed to the chamber bottom with electrical tape. Running seawater was supplied through a tube fixed at one end of the chamber attached to a $2 \mathrm{~cm}$ diameter plastic $\mathrm{T}$-joint with 20 uniformly spaced $1.5 \mathrm{~mm}$ diameter holes drilled along its length. The T-joint was embedded in polyester resin so the water flow coming out of the holes was parallel to the chamber bottom $1 \mathrm{~mm}$ above the plate surface. The opposite end of the chamber was removed and replaced with 
$0.45 \mu \mathrm{m}$ Nitex $^{\otimes}$ mesh that let water out. The flow chamber was set on bricks in an opaque plastic enclosure. On clean surfaces, the flow was relatively laminar in the central portion of the plate $(5 \times 5 \mathrm{~cm})$ when checked with dye tracers and polyethylene, 150 to $250 \mu \mathrm{m}$ particles.

Four flow rates were used in the flow chamber to examine the influence of water flow on the exploratory behavior of larvae: $0,1.3,6.1$ and $8.3 \mathrm{~cm} \mathrm{~s}^{-1}$. These will be referred to as still water, and low, medium and high flow rates respectively. These flow rates were the overall flow rates in the chambers. Actual speeds near the plate surface were lower. Flow speeds near the plate surface were further reduced and highly variable when micro-topographic complexity was present (i.e. biofouling structures). This was especially true when flexible, arborescent structures, such as hydrozoans, moved in the flow. Due to this inherent variability and the variability associated with larval contact location and direction of exploration, we did not attempt to quantify exact flow rates at the surfaces. A similar chamber (with no water inlet or outlet) was used for experiments in the still water treatment. Trials were run for each surface type and flow rate combination (total of 16 treatments) until data were collected for 5 individuals or a total of 500 larvae were introduced into the system with a pipette 5 to $10 \mathrm{~mm}$ upstream of the endoscope. Five to ten larvae were injected at a time. Individual observations began within $60 \mathrm{~s}$ of larval additions, providing observed individuals with sufficient time to respond to the flow and surface cues. Observations continued until each individual settled or actively or passively left the surface.

Endoscopic examination and video recordings. The endoscope and video tape recording set-up has been previously described (Ward et al. 1991, Miron et al. 1996b). The endoscope (Olympus, K17-18-00-62) with a $1.75 \mathrm{~mm}$ diameter optical insertion tube (OIT), $186 \mathrm{~mm}$ in length, was attached to a monochrome charge-coupled-device video camera (Cohu Inc.) via a C-mount zoom adapter (Schölly Fiberoptics $\mathrm{GmbH}_{\text {, }}$ W-7819), allowing magnification up to $150 \times$. The camera was fastened to a micromanipulator (World Precision Instruments M3301R), allowing 3-dimensional movement inside the flow chamber. Video output from the camera was sent to a 4-head VCR (Panasonic VHS, $A G-6010 S$ ) and then to a monochrome video monitor. A $250 \mathrm{~W}$ high-intensity xenon light source (Olympus ILV-2) provided cold light to the tip of the OIT via an external fiber optic light guide. A cardboard panel, placed over the external enclosure, eliminated other external light sources inside the flow chamber. The endoscope apparatus has a $55^{\circ}$ angle of view and a depth of field from $1 \mathrm{~mm}$ to infinity. The OIT was set 2 to $4 \mathrm{~cm}$ from the plate surface and provided a top view of the larva while exploring the substrata. The observational period varied from seconds to hours depending on the time each larva took to (1) settle. (2) actively swim away from the substrata or (3) be passively transported out of the recording field.

To analyze the behavior of larvae, recorded larval movements (trails) were transferred manually from a 17 -inch video monitor (Panasonic WV5470) to clear transparency sheets. We recorded the location of each larva every time it changed location in the $X, Y$, and $Z$ directions up to 30 times $\mathrm{s}^{-1}$. Trails on transparencies were digitized on a Sumagraphics digitizing tablet, and the coordinate points $(X, Y)$ and direction of travel were determined using AutoCad software. The $Z$ coordinate was estimated directly from video tapes as (1) on the surface, (2) within a millimeter of the surface or (3) $>1 \mathrm{~mm}$ above the surface.

Data analyses. The following response variables were studied for all individuals of each species: (1) total area covered by larvae, (2) number of larvae that settled, (3) total time larvae were observed (until actively or passively lost from the surface) and (4) number of larvae that actively explored surfaces after contact. The total area covered by larvae was estimated using fractal dimensions (e.g. Dicke \& Burrough 1988, Erlandsson \& Kostylev 1995). For the analysis, each plotted trail is described using the box-counting method (Hastings \& Sugihara 1993), which gives an estimation of the area occupied by a trail (Erlandsonn \& Kostylev 1995). The fractal dimension is then calculated from $B=t D$, where $t$ is $1 /$ (square box size) and $B$ is the number of boxes covered by the trail. Box size is the length of 1 side of a box. If $D=1$, then linear movement is described; $D=1.5$ describes Brownian motion (Hastings \& Sugihara 1993). A balanced-design 2-way ANOVA was run for each response variable after data were arcsine transformed to ensure normality of means and homogeneity of variances (Zar 1984). Flow rate, surface type and the interaction effect were compared simultaneously incorporating all larvae in all treatments ( $N=5$ in each cell). Where overall differences were significant, Tukey's multiple comparisons tests were used to determine which means were different. All statistical analyses were run in SAS 6.08 (SAS Institute 1988).

A second set of variables were considered only for individuals that actively explored surfaces: (1) direction of movement relative to flow, (2) exploration distance in millimeters, (3) exploration speed in millimeters per second and (4) proportion of time (in seconds) spent in different behavioral categories (time budgets). As larvae did not explore surfaces in all treatments, an unbalanced design resulted. Thus, separate 1-way ANOVAs were used to determine if surface type or flow rate influenced larval behavior with 
respect to these variables. Where overall differences were significant $(p<0.05)$, Tukey's multiple comparisons tests were used to determine which means were different

Finally, we determined the behavioral sequences for each species during exploration for each surface/flow rate combination to better understand the potentially complex range of activities of exploring Balanus amphitrite and Bugula neritina. We calculated the percentage of times a behavior was continued once it began versus changing to a different behavior (Lehner 1979). Data are presented 2 ways. First, all flow rates are confounded with surface treatment. Then, values for all surface types are confounded within flow rates.

\section{RESULTS}

\section{Larval movements and settlement}

The area covered by the larvae ranged from near straight lines (Fig. 1A, fractal dimension $D=1.0203$ ) to near complete surface coverage (Fig. $1 B, D=1.43$ ). For Balanus amphitrite, surface area covered was significantly greater in moving water (Table 1, Fig. 2) For Bugula neritina, both surface type and flow influenced the area covered by individuals. Larvae contacted more area on biofilmed or fouled surfaces than on clean surfaces (Table 1), due to a combination of individuals crawling over more area and actively hanging on to filaments as the filaments were moved in the flow. Trajectory fractal dimensions were also greatest at medium flow for $B$. neritina (mean $\pm \mathrm{SE}=1.3 \pm 0.01$ ), again through a combination of active exploration and attachment to filaments. At the $1.3 \mathrm{~cm} \mathrm{~s}^{-1}$ flow, all larvae crawled directly upstream until they were out of range and never attached exclusively to filaments $(1.15 \pm 0.01)$; at high flow, most larvae were eroded away and lost as passive particles $(1.11 \pm 0.01)$.

Settlement and metamorphosis occurred for a total of 6 of 80 individuals of Balanus amphitrite and 7 of 80 observed Bugula neritina. We observed no correlation with flow rate or surface types for settling $B$. amphitrite (Table 1). For $B$. neritina, settlement was significantly greater on the $2 \mathrm{wk}$ fouled plates (Table 1). In fact, larvae of $B$. neritina only settled on 2 wk fouled surfaces
Bugula neritina: $1.3 \mathrm{~cm} \mathrm{~s}^{-1}$ flow

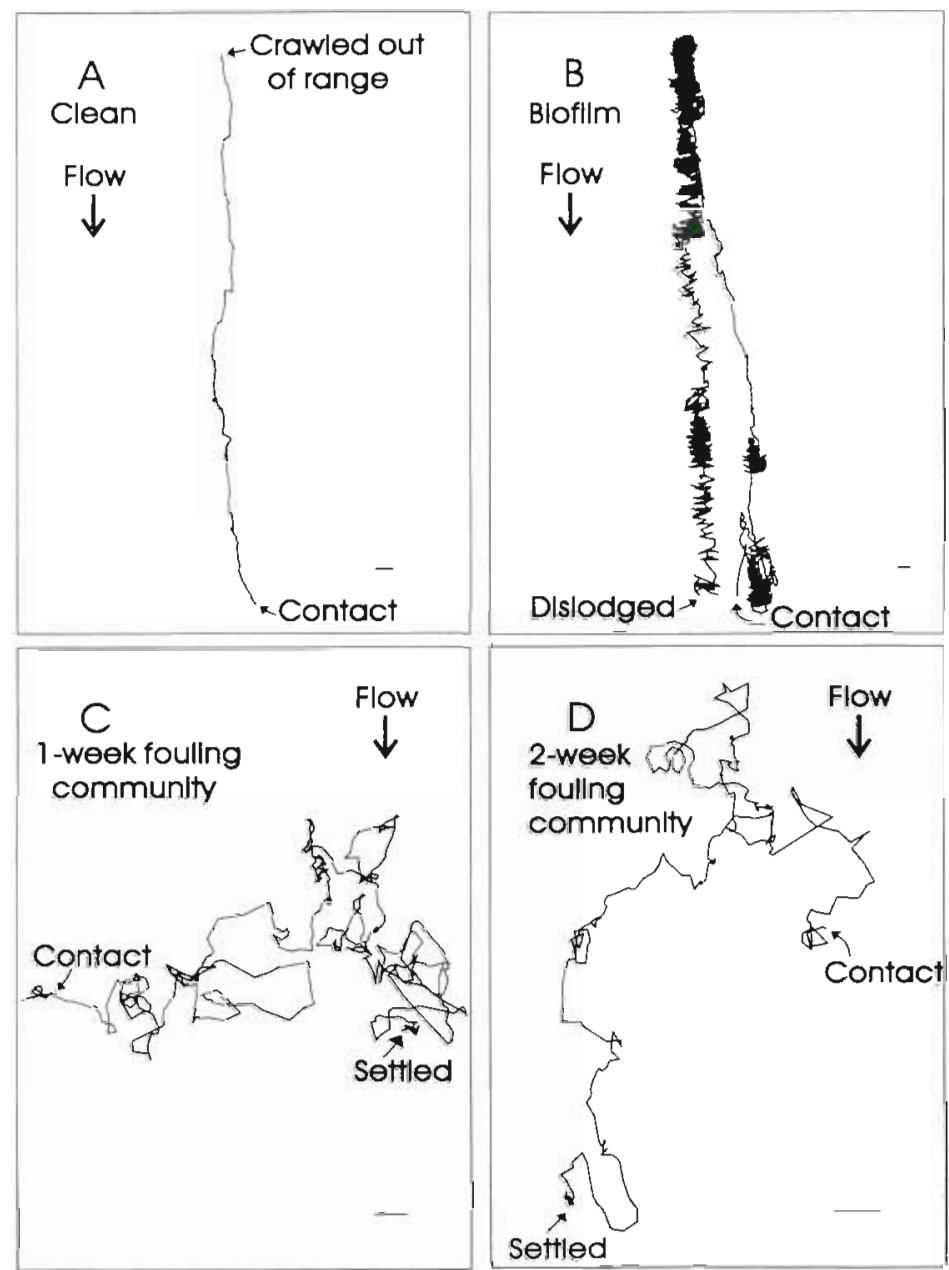

Fig. 1. Bugula neritina. Representative examples of paths of individual larvae from contact through settlement or loss (crawled out of range, passive dislodgment) on the surfaces specified in each frame at $1.3 \mathrm{~cm}$ $\mathrm{s}^{-1}$ flow. (A) On a clean surface, a larva of $B$. neritina continuously crawled upstream in almost a linear fashion, never leaving the substratum and never settling. This individual crawled out of range at 3 min $19 \mathrm{~s}$. (B) On a surface with a biological film, the larva also attempted to crawl directly upstream. However, on this surface, it frequently became entangled in filaments associated with bacteria and microflora. When this occurred, the larva clung to the filaments and was bounced in all directions between 10 and 30 times $\mathrm{s}^{-1}$. The larva then moved downstream, likely moving from filament to filament, as no filaments became detached during the process. However, when the individual hit the hard surface in a certain orientation, it immediately released and resumed crawling directly upstream. This individual was followed for $44 \mathrm{~min}$ and $30 \mathrm{~s}$, of which it adhered to a filament $48 \%$ of the time. In spite of the tenacity of this individual, it was passively dislodged while attached to a filament at almost the same location as it initially contacted the surface. (C,D) On surfaces with macro-topographic features, larvae explored by crawling in all directions, including around and over topographic features $(C, D)$. On the $1 \mathrm{wk}$ fouled surface, the individual ceased exploration and began metamorphosis at 8 min $57 \mathrm{~s}$ (C). On the 2 wh fouled surface, settlement began after 5 min $17 \mathrm{~s}$ (D). On the 2 wk fouled surface, for $15 \%$ of this exploration time, the larva was able to swim short distances directly above the surface $(<1 \mathrm{~mm})$, sometimes spinning in circles as has been described in still water (Woollacott \& Zimmer 1971). All scale bars $=1 \mathrm{~mm}$ 
Total time of observation for larvae of Balanus amphitrite was influenced by plate type (Table 1). Larvae spent more time on 2 wk fouled surfaces (mean \pm $\mathrm{SE}=259.5 \pm 80.7 \mathrm{~s})$ than on clean $(89.4 \pm 52.8 \mathrm{~s})$ or biofilmed (14.2 \pm 5.4 s) surfaces. Total time on plates for Bugula neritina was significantly influenced by both plate type and flow rate, and the plate type $x$ flow

Balanus amphitrite: 2-week community
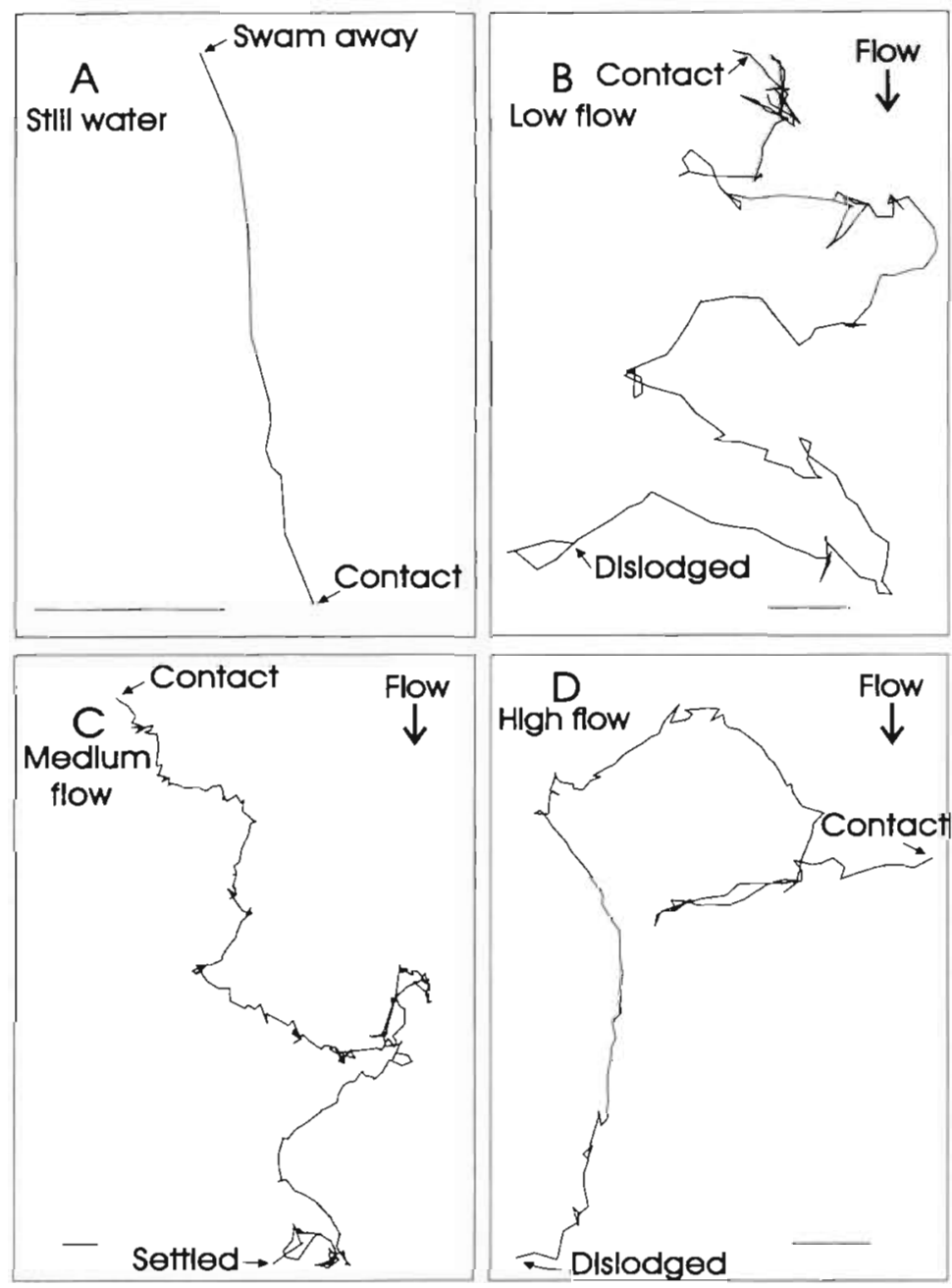

Fig. 2. Balanus amphitrite. Representative examples of paths of individual larvae from contact through settlement or loss (actively swimming away, passive dislodgment) at the flow rates specified in each frame on surfaces with a 2 wk fouling community. (A) In still water, $B$ amphitrite spent little time ( $37 \mathrm{~s}$ ) on the $2 \mathrm{wk}$ fouled surface. Of this time, the individual remained stationary for $27 \mathrm{~s}$. When the individual moved, it moved in nearly a straight line. (B,C,D) At the 3 tested flow rates, individuals moved in all directions relative to flow, always ending downstream of their contact location. At all flow rates, larvae spent time actively maintaining their position. At the lowest flow rate, the larva. remained stationary $25 \%$ of its 10 min $35 \mathrm{~s}$ on the surface (B). At the intermediate flow rate, the individual was stationary for $13 \%$ of $16 \mathrm{~min}$ 56 s until settlement occurred (C), and at the highest flow rate, the individual was stationary for $7 \%$ of its 3 min $2 \mathrm{~s}$ on the plate (D). All scale bars $=1 \mathrm{~mm}$ rate interaction (Table 1). At most flow rates, larvae spent the least amount of time on clean surfaces $(80.6 \pm$ $27.9 \mathrm{~s}$, Table 1). Larvae also spent more time on surfaces at $1.3 \mathrm{~cm} \mathrm{~s}^{-1}$ flow than at any other flow rate $396.1 \pm 139.2 \mathrm{~s}$, Table 1$)$. This flow rate was apparently not sufficient to induce settlement or to induce larvae to actively leave the surface. Larvae actively swam off surfaces in still water, but larvae either settled or were passively removed at flow rates of 6.1 and $8.3 \mathrm{~cm} \mathrm{~s}^{-1}$.

The number of larvae of Balanus amphitrite that actively explored surfaces was significantly greater if macrofouling was present on the surface (Table 1). Similarly, individuals of Bugula neritina were actively rejected or dislodged from surfaces significantly more often if the surfaces were clean (Table 1). The number of larvae of $B$. neritina likely to explore a surface was inversely proportional to flow rate.

\section{Trajectory analysis of exploring individuals}

Neither surface type nor flow rate influenced the direction of travel relative to flow for Balanus amphitrite. On all surface types and at all flow rates, cyprids were able to move perpendicular to the direction of water flow (Fig. 3A). However, the trajectory of larvae of Bugula neritina was significantly influenced by both variables (Fig. 3A). Larvae headed into the flow more frequently if the surface was clean or had only a microbial film than if it was covered by macroinvertebrates (Fig. 3A). Additionally, larvae of $B$. neritina headed into the flow most often at the $1.3 \mathrm{~cm} \mathrm{~s}^{-1}$ (low) flow rate (Fig. 3A).

Total exploration distance in millimeters varied greatly among individuals of Balanus amphitrite (Fj.g. 3B). For most variables, the mean distance covered by larvae of Bugula neritina was greater than that of $B$. amphitrite (Fig. 3B). Additionally, larvae of B. neritina covered a greater distance at the $1.3 \mathrm{~cm}$ $\mathrm{s}^{-1}$ (low) flow than in either still water or in $6.1 \mathrm{~cm} \mathrm{~s}^{-1}$ (medium) flow (Fig. 3B).

Mean exploration rate of Balanus amphitrite did not differ among treatments and ranged from 0.16 to $0.21 \mathrm{~mm} \mathrm{~s}^{-1}$ (Fig. 3C). Movement of Bugula neritina was much faster, with a maximum of $0.82 \mathrm{~mm} \mathrm{~s}^{-1}$ in still water (Fig. 3C). This was partly due to cyprids of $B$. amphitrite spending large 
Table 1. Analysis of all individuals. A balanced-design, 2-way ANOVA with plate type, flow rate and plate $x$ flow interaction as the factors incorporating all larvae in all treatments ( $N=5$ in each cell) was run for each response variable listed below. The p-values for each variable are presented. When overall differences were significant $(p<0.05)$, results of Tukey's multiple comparison tests were used to determine which means were different (Rank). Fractal dimension: number between 1.0 and 1.5 based on the amount of area covered by an individual; settlement: total number of individuals that settled total time of observation: time

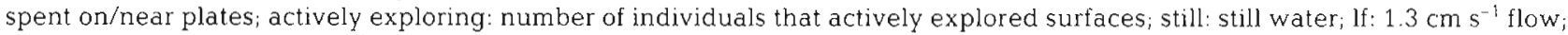
$\mathrm{mf}: 6.1 \mathrm{~cm} \mathrm{~s}^{-1}$; hf: $8.3 \mathrm{~cm} \mathrm{~s}^{-1}$; bf: biofilm; $\mathrm{f} 1: 1 \mathrm{wk}$ fouling community; $2: 2 \mathrm{wk}$ fouling community

\begin{tabular}{|c|c|c|c|c|c|}
\hline Species & Response variable & Plate & Flow & Plate $\times$ Flow & Rank \\
\hline \multirow[t]{4}{*}{ Balanus amphitrite } & Fractal dimension & 0.0575 & 0.0008 & 0.0868 & Flow: lf $=\mathrm{mf}=\mathrm{hf}>$ still \\
\hline & Settlement & 0.3125 & 0.3125 & 0.4111 & \\
\hline & Total time of observation & 0.0018 & 0.0719 & 0.1951 & Plate: $\mathrm{f} 2$ fl clean bf \\
\hline & Actively exploring & 0.0001 & 0.0001 & 0.0153 & $\begin{array}{l}\text { Plate: } \mathrm{f} 2=\mathrm{f} 1>\mathrm{bf}=\mathrm{clean} \\
\text { Flow: still }>\mathrm{lf}=\mathrm{mf}=\mathrm{hf}\end{array}$ \\
\hline \multirow[t]{4}{*}{ Bugula neritina } & Fractal dimension & 0.0001 & 0.0001 & 0.0001 & $\begin{array}{l}\text { Plate: } \mathrm{bf}=\mathrm{f} 1=\mathrm{f} 2>\text { clean } \\
\text { Flow: } \mathrm{mf}>\text { still }=1 \mathrm{f}=\mathrm{bf}\end{array}$ \\
\hline & Settlement & 0.0011 & 0.5756 & 0.4572 & Plate: $\mathbf{f} 2>$ clean $=$ bf $=\mathrm{f} 1$ \\
\hline & Total time of observation & 0.0339 & 0.0045 & 0.0074 & $\begin{array}{l}\text { Plate: } \text { bf } \mathrm{f} 2 \mathrm{f} 1 \mathrm{clean} \\
\text { Flow: } \mathrm{lf}>\mathrm{still}=\mathrm{mf}=\mathrm{hf}\end{array}$ \\
\hline & Actively exploring & 0.0001 & 0.0001 & 0.0001 & $\begin{array}{l}\text { Plate: } \mathrm{f} 2=\mathrm{f} 1=\mathrm{bf}>\text { clean } \\
\text { Flow: still }=\mathrm{lf}>\mathrm{mf}>\mathrm{hf}\end{array}$ \\
\hline
\end{tabular}

amounts of time remaining stationary between hops, while larvae of $B$. neritina moved nearly $100 \%$ of time on all surfaces at all flow rates. In moving water, most $B$. neritina remained in constant contact with the plate surfaces. In still water, individuals combined crawling with near-surface swimming, and when they did, they covered the substratum significantly faster than when only crawling was used (Fig. 3C).

\section{Larval behaviors}

For Balanus amphitrite, the observed behaviors included crawling, swimming, actively attaching to filaments, no movement while lying on the surface (stationary), standing still or rotating on antennules, hopping, and side-crawling (Fig. 4). Hopping was defined as short, individual jumps that were initiated by stationary individuals. Side-crawling behavior was only observed in still water (ANOVA: $p=0.0001$ ), with individuals crawling over the surface on their sides by moving their thoracic appendages.

For larvae of Balanus amphitrite that contacted surfaces, the proportional amount of time spent hopping was very variable and did not differ among surface types or flow rates. However, the amount of time spent motionless was significantly less on biofilmed surfaces (6\% of time vs $46 \%$ for all other surfaces combined; ANOVA: $p=0.0036$ ). The maximum stationary period for an individual cyprid was 497 s. Between hops, individuals also spent time standing on their antennules, sometimes changing directions. This behavior was most frequent on 1 and 2 wk fouled surfaces (Fig. 4;
ANOVA: $p=0.0031$ ). Additionally, it occurred more at the high and medium flow rates than the low flow rate, and significantly less again in still water (Fig. 4; ANOVA: $p=0.0001$ ). Crawling and swimming were also observed for larvae of $B$. amphitrite. Of these behaviors, only crawling was influenced by surface treatment, with more crawling occurring on fouled plates (Fig. 4; ANOVA: $\mathrm{p}=0.0078$ ).

Larval behaviors observed for Bugula neritina included swimming, spinning, crawling, actively attaching to filaments and remaining stationary. Swimming was observed significantly more often on all surfaces in still water than in any flow treatments (Fig. 4; ANOVA: $p=0.0001$ ). Spinning took place when larvae were in direct contact with the surface or directly above it and was not influenced by surface type or flow rate. Flow significantly increased the proportion of time spent crawling (Fig. 4; ANOVA: $p=0.0001$ ). The proportion of time actively spent on filaments on surfaces with micro- or macrofouling did not differ with plate type, but did differ with flow rate. Larvae spent more time on filaments at medium and high flow than at low flow or in still water (Fig. 4; ANOVA: $\mathrm{p}=0.0001$ ). The amount of time a larva remained stationary was always low (maximum time $=32 \mathrm{~s}$; mean time $\pm \mathrm{SE}=3.31 \pm 0.97 \mathrm{~s}$ ) and did not differ among treatments.

\section{Larval time budgets}

We determined the likelihood that a behavior would continue once it began until the individual settled or actively or passively left the surface (Figs. 5 \& 6). Larvae 
A. Direction of Exploration Relative to Flow

$(0=$ toward flow, $1=$ with flow $)$
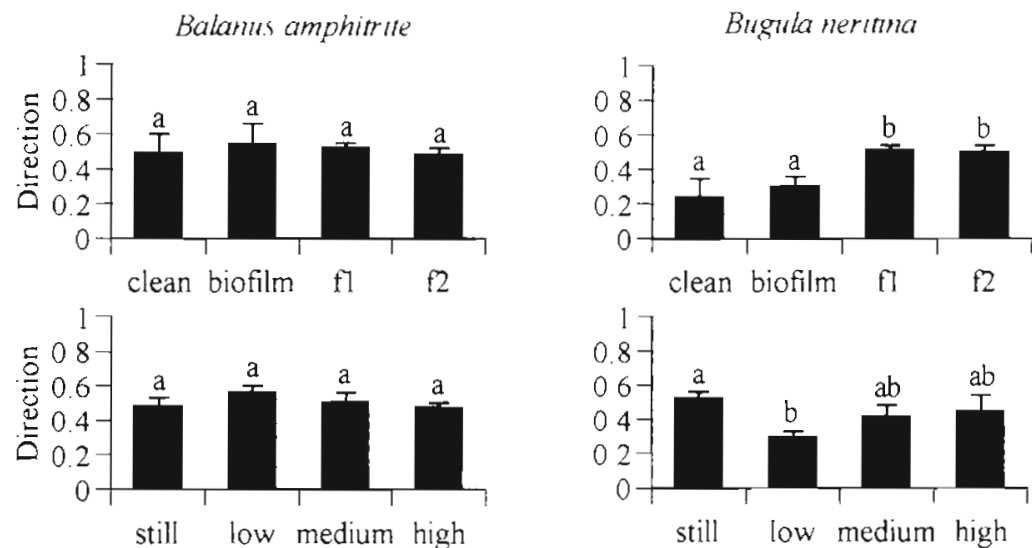

B. Total Exploration Distance (mm)

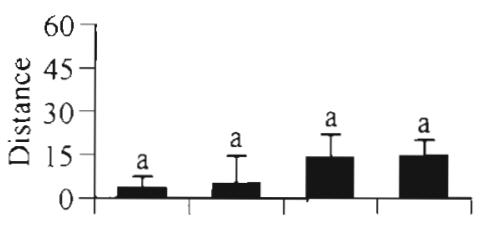

clean biofilm $\mathrm{fl} \quad \mathrm{f2}$

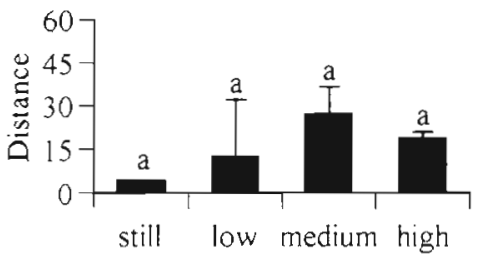

C Exploration Rate $\left(\mathrm{mm} \mathrm{s}^{-1}\right)$
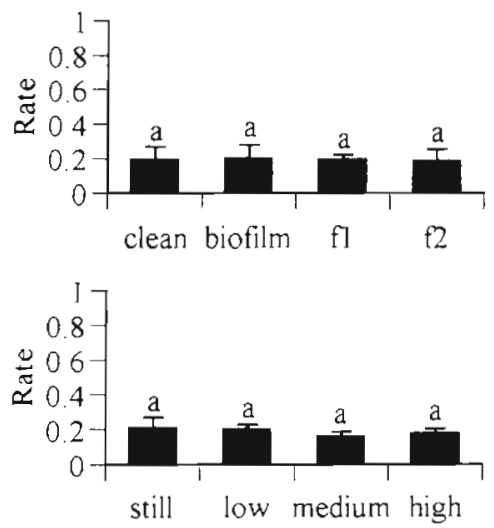

Fig. 3. Analysis of explonng individuals. As Larvae were unable to actively explore under certain surface type $\times$ flow rate combinations, separate 1 -way ANOVAs were run to determine if plate type or flow rate influenced behavior of larvae of Balanus amphitrite and Bugula neritina. The mean $\pm \mathrm{SE}$ are presented for each treatment for $(A)$ direction of exploration relative to flow $(0=$ directly into flow; 1 = directly with flow), (B) total exploration distance (mm) and $(C)$ exploration speed $\left(\mathrm{mm} \mathrm{s}^{-1}\right)$. Where overall differences were significant $(p<0.05)$. Tukey's multiple comparison tests were used to determine which means were significantly different. Different letters refer to means that were significantly different of Balanus amphitrite exhibited many behaviors. For example, between hops, often larvae first were stationary, next stood on their antennules and then were stationary again (Fig. 5). Cyprids also frequently remained in the same position before and after crawling (Fig. 5). Unlike B. amphitrite, larvae of Bugula neritina spent most of their time crawling or actively attached to filaments (Fig. 6). The latter behavior ended either in a return to crawling or passive dislodgment from the surface. In still water and on 2 wk fouled plates, some near-surface swimming was also occasionally observed (Fig 6).

\section{Importance of light on settling larvae}

Light has long been known to influence larvae of Bugula neritina, with individuals switching from a photopositive to a photonegative behavior when the swimming phase ended (Lynch 1947). In our trials, newly released larvae of $B$. neritina only swam toward the endoscope light source in still water. In flow, similar age larvae immediately contacted the bottom and remained in contact with it until settlement occurred or the individual was dislodged from the surface. No individuals ever purposely left a surface after contact in moving water. Additionally, when tested on clean surfaces at $1.3 \mathrm{~cm} \mathrm{~s}^{-1}$, regardless of the location of the endoscope light source relative to larvae and direction of flow, all larvae continued to crawl directly upstream.

\section{DISCUSSION}

The most important event in the life cycle of a sessile invertebrate is likely to be selecting where to settle (Bourget 1988). Exploration of a surface by a larva should increase the individual's chances of finding a site that will optimize fitness. Until now, direct observations of larvae in flow on surfaces with biological fouling have not been possible. With the use of endoscopy, we have demonstrated the enormous range 
Fig. 4. Time budgets for larvae of Balanus amphitrite and Buguia neritina. ln treat ments where active exploration occurred, sections of each pie chart represent the mean proportion of time each behavior was observed If no larvae explored the surface in a surface type $x$ flow rate treatment, ther the pie chart is cross-hatched

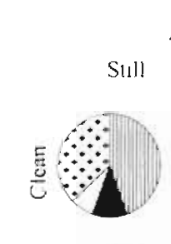

Balanus amphitrite
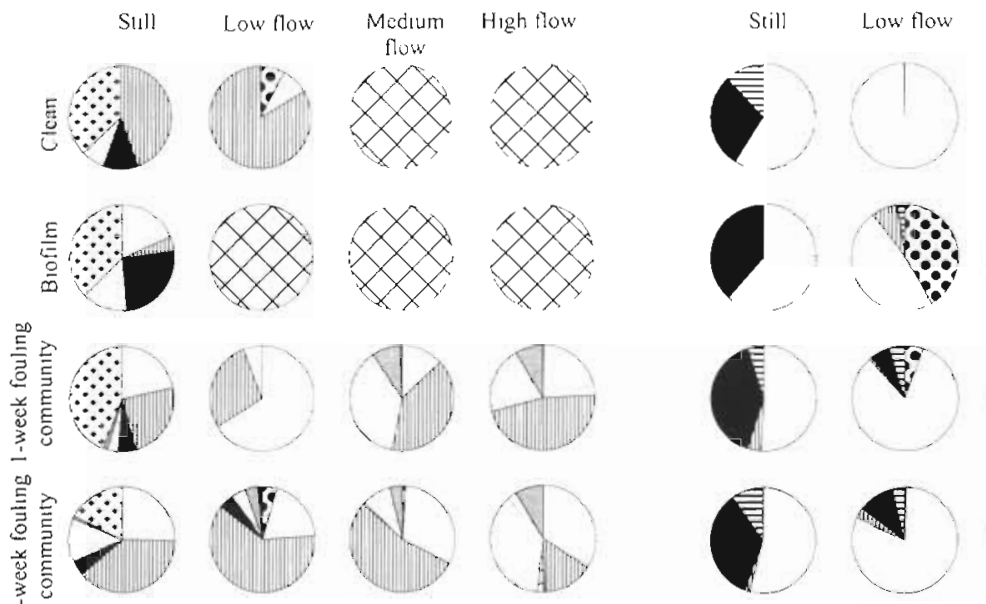

Bugula neritina
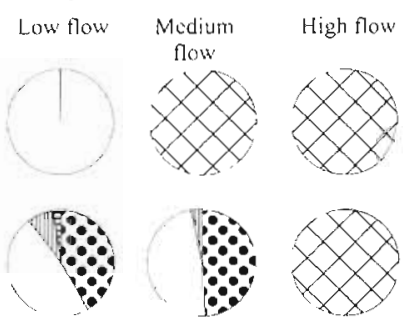

Х

On filaments

Crawl IIIIII Stationary

Swim

Or antennules
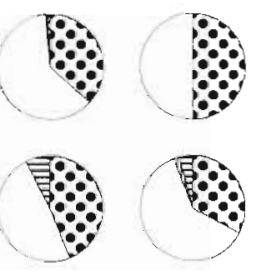

of post-contact exploratory behaviors by larvae of Balanus amphitrite and Bugula neritina. Our results also clearly demonstrate that both flow rate and micro- and macro-organisms previously recruited to the surface can significantly influence larval exploration and, thus, ultimately the selected settlement site. Interestingly, the range of behaviors observed for the competent larval forms of each species to the 16 flow by surface type combinations were different from one another in most cases (Figs. 3 to 6, Table 1). Rittschof \& Costlow (1989) also found different behaviors when larvae of $B$. amphitrite and $B$. neritina were compared in laboratory settlement assays. A similar negative correlation was found with these species in field settlement trials (Roberts et al. 1991).

\section{Larval site selection}

To maximize fitness, larvae should seek locations where (1) attachment is secure, (2) predation and physical disturbances are minimized and (3) food availability is greatest. Although clean surfaces should provide the best attachment for settlement adhesives, larvae rarely settled on these surfaces. Instead, highly fouled surfaces were preferred by larvae of Bugula neritina, and settlement of larvae of Balanus amphitrite did not differ between plate types (Table 1). However, while remaining in a fixed location ( $B$. amphitrite) or spinning ( $B$. neritina), individuals may have removed any detritus, biological films or settled organisms from a potential attachment location. Interestingly, Hudon et al. (1983) and LeToumeux \& Bourget (1988) found that, on a $1 \mathrm{~mm}$ scale, larvae of the barnacles Balanus crenatus and Semibalanus balanoides selected clean sites, devoid of detritus and diatoms. However, on a $1 \mathrm{~m}$ scale, larvae of $S$. balanoides selected areas well colonized by the diatom Achnantes parvula. Additionally, in still water, Crisp \& Austen (1960) found that when larvae of $S$, balanoides encountered loose objects, including algal filaments, silt particles or air bubbles, they frequently swam away, patentially due to poor adhesion.

Secure attachment is also likely to be found in pits on the size-scale of a larva or smaller. LeTourneux \& Bourget (1988) found that larvae of Semibalanus balanoides preferentially settled in locations with greater microheterogeneity (scale: $<300 \mu \mathrm{m}$ ) than adjacent areas. In field trials, Walters \& Wethey (1996) also found that within $24 \mathrm{~h}$ intervals, significantly more newly settled individuals of both Balanus amphitrite and Bugula neritina were found in crevices formed on surfaces where the bases of 2.0 and $5.0 \mathrm{~mm}$ high roughness elements intersected the flat surface. In our trials, on 1 and $2 \mathrm{wk}$ fouled surfaces, all larvae encountered 1 or more crevices during exploration (L.J.W. pers. obs.). However, only $15 \%$ of the B. amphitrite and $18 \%$ of the larvae of $B$. neritina settled on these surfaces and, of those that settled, none did so in crevices created by previously recruited barnacles.

In addition to providing secure attachment, crevices can potentially provide new recruits with protection from predation and physical disturbance events. Walters \& Wethey (1996) found that short-term survival (up to 1 wk post-settlement) of both Balanus amphitrite and Bugula neritina in Beaufort waters was signifi- 
Balanus amphitrite Flow rate confounded within plate treatment
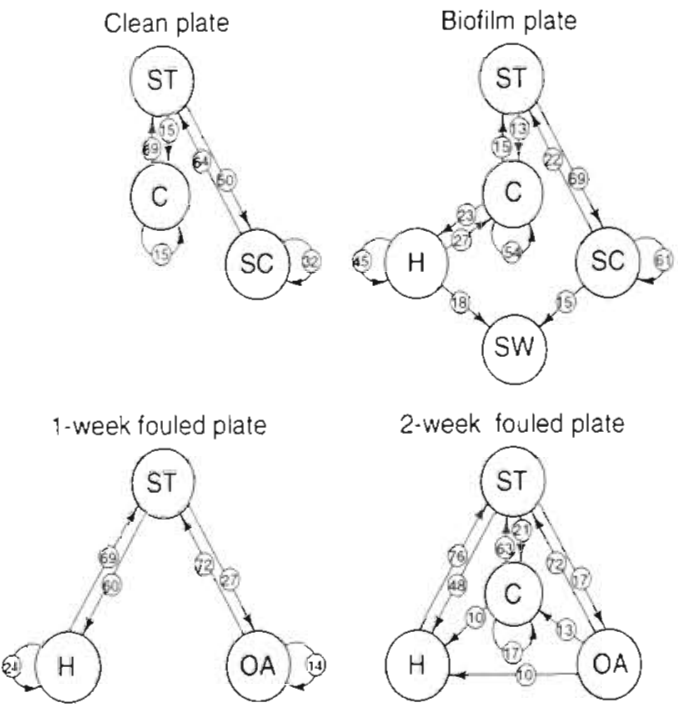

Balanus amphitrite

Plate treatment confounded within flow rate
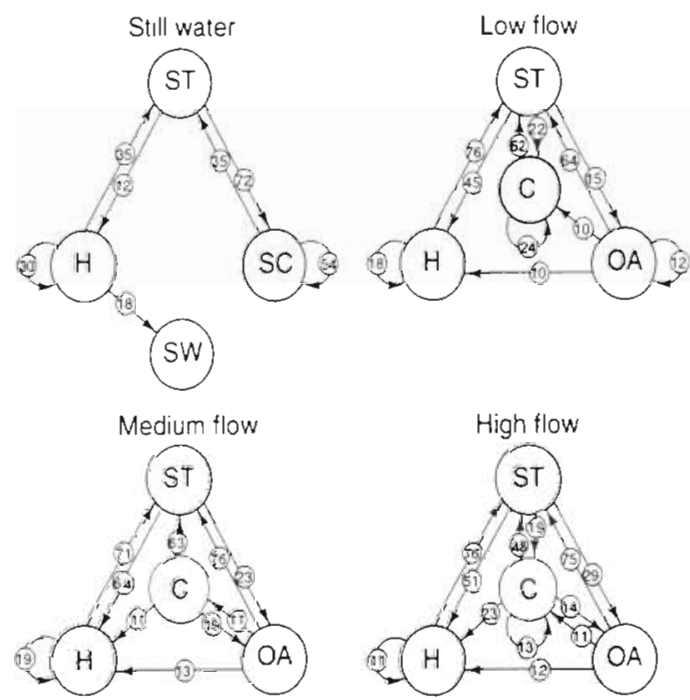

ST: stationay

\section{$\mathrm{SC}$ : side-crawling} $\mathrm{OA}$ : on antennules

C: crawling $H$ : hopping

Fig. 5. Balanus amphitrite. Behavioral sequences during larval exploration for (A) a given surface type and (B) flow rate. Numbers in circles represent the probability $(\%)$ of occurrence of a transition when a given behavior has been executed. In (A), percentages were obtained from the integration of all behavioral sequences observed in all flow rate situations within a given surface type. In (B), percentages were obtdined from the integration of all sequences observed from all surface treatments within a given flow rate. For clarity, only

transitions that had at least $10 \%$ occurrence were drawn

cantly greater in crevice locations than on exposed surfaces. However, in our study, larvae did not settle in crevices. All settled individuals were within millimeters of recruits that either potentially provided suffi-
Bugula neritina

Flow rate confounded within plate treatment
Clean plate

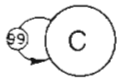

1 week fouled plate

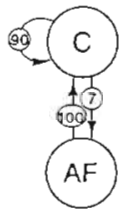

Biofilm plate

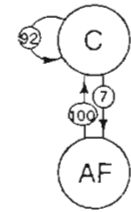

2 week fouled plate

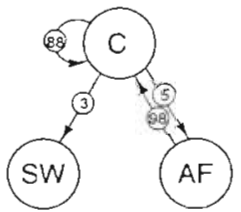

Bugula neritina

Plate treatment confounded within flow rate
Still water

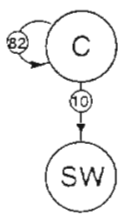

Medium flow

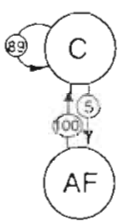

B$$
\text { SW }
$$

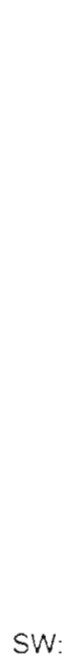

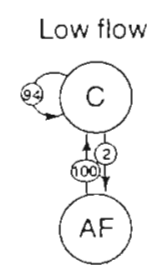

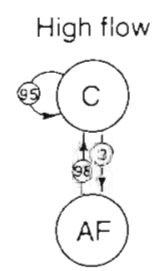

Fig. 6. Bugula neritina. Behavioral sequences during larval exploration for (A) a given surface type and (B) flow rate. Numbers in circles represent the probability $(\%)$ of occurrence of the transition when a given behavior has been executed. In (A), percentages were obtained from the integration of all behavioral sequences observed in all flow rate situations within a given surface type. In (B), percentages were obtained from the integration of all sequences observed from all surface treatments within a given flow rate. All occurrences were drawn

cient refuge or chemically induced the larvae to settle. The difference may be due to the roughness elements themselves. Walters \& Wethey (1996) observed settlement preferences on roughness elements created from polyester resin, while in the present observations, the roughness elements were primarily barnacles. We observed the filter-feeding apparatus of juvenile and adult barnacles actively dislodging all cyprids that 
attempted to settle in contact with their shells. This observation of recruits physically dislodging potential settlers may explain Wethey's (1984) finding that larvae of Semibalanus balanoides consistently settled close to conspecific cyprids, but not to metamorphosed individuals. It may also provide some explanation for the 'territorial' behavior of newly settled spat observed by Crisp (1961). Miron et al. (1996a), however, found that larvae of $B$. crenatus frequently metamorphosed on adults, and their fitness was greatest in this location.

Fitness also depends on food availability. For these 2 filter-feeding organisms, food availability should be greatest in locations where flow rates are highest. Thus, to obtain the most food, larvae should seek the highest flow they can endure. On surfaces with no macrofouling, larvae of Bugula neritina were significantly influenced by flow rate and individuals crawled directly upstream at all flow rates (Figs. 1 \& 3). In low flow treatments, the lack of settlement may have been the result of individuals not finding sufficient flow. Larvae of Balanus amphitrite appeared to be less influenced by flow rates as long as the water was moving Only the percentage of time spent tumbling passively and standing on antennules differed with flow rate (Fig. 5). In laboratory trials with larvae of Semibalanus balanoides, Crisp \& Austen (1960) also suggest that water current had little effect on individuals, except possibly to dislodge them, while Miron et al. (1996a) found that, regardless of where individuals initially contacted plates, larvae of $B$. crenatus preferentially settled on the sides of adult shells where water flow was greatest.

\section{Importance of flow on settlement}

Like Bugula neritina, larvae of other species also seem to avoid settling in low flow conditions. The tubeworm Phragmatopoma lapidosa californica avoided settling in $5 \mathrm{~cm} \mathrm{~s}^{-1}$ flow (Pawlik et al. 1991). At this speed in the flume, larvae remained suspended or swam upward if they contacted the bottom. However, in their high flow treatment $\left(15 \mathrm{~cm} \mathrm{~s}^{-1}\right)$, larvae actively swam to the bottom and tumbled along in bedload transport until a positive chemical cue was encountered (Pawlik et al. 1991). Also in flume trials, Mullineaux \& Butman (1991) found that $60 \%$ of cyprid larvae of Balanus amphitrite contacting settling plates moved from their initial contact location while remaining close to the surface. The proportion exploring at 5 and $10 \mathrm{~cm} \mathrm{~s}^{-1}$ was similar, but there was more downstream exploration at $10 \mathrm{~cm} \mathrm{~s}^{-1}$. Larvae also left surfaces more frequently at the high flow rate, although, according to Eckman et al. (1990), all flow rates were below the critical value needed to physically dislodge larvae $\left(1.32 \times 10^{5} \mathrm{dyn} \mathrm{cm}^{-2}\right)$. Prior to their trials, settlement surfaces were soaked in seawater extracts of conspecific individuals (Mullineaux \& Butman 1991). Trial duration was then either 24 or $48 \mathrm{~h}$. A biological film likely formed during this period. If this film contained any arborescent filaments, the potential exists that their loss of larvae was due to entanglement in filaments and subsequent passive erosion rather than active rejection of the surface.

\section{Importance of other organisms on settling larvae}

While exploring, larvae frequently encountered other mobile invertebrates, including conspecific larvae, carnivorous polychaete worms, and amphipods of the genus Corophium.

When larvae encountered each other, there was little interaction. In only 1 instance did 2 individuals of Bugula neritina remain in contact for $5 \mathrm{~s}_{i}$ in all other cases, after contact was made, the larvae crawled away in different directions. When larvae of either Balanus amphitrite or $B$, neritina encountered amphipods or polychaetes on the fouled plates, the larvae continued moving in the same or slightly altered paths (L.J.W. pers. obs.). Neither species attempted to flee by swimming away, even when repeatedly contacted by these much larger invertebrates. Both species were also observed to travel through mud tubes abandoned by amphipods and underneath detrital mats. Additionally, we observed larvae of $B$. amphitrite teaming up to dislodge a recently metamorphosed barnacle (L.J.W. pers. obs.).

Larval settlement may also be negatively correlated with resident individuals if the residents prey on larvae or discharge nematocysts when contacted. Sessile invertebrates, especially solitary ascidians, have been found to consume large numbers of invertebrate larvae (e.g. Bingham \& Walters 1989, Osman et al. 1989). Osman et al. (1989) found that $96 \%$ of larvae of the oyster Crassostrea virginica added to tanks containing the solitary ascidian Styela clava were eventually found in fecal pellets of the ascidians. In our study, no predation was observed. Occasionally, cyprid larvae were engulfed by adult barnacles (L.J.W. pers. obs.). These cyprids were rapidly rejected. Likewise, larvae of Bugula neritina swam in and out of the siphons of $S$. plicata before ingestion ever occurred (L.J.W. pers. obs.). Two sessile invertebrates frequently contacted by larvae of Balanus amphitrite and $B$. neritina on fouled surfaces were the nematocyst-containing arborescent hydroids Tubularia crocea and Eudendrium carneum. Larvae of $B$. neritina were extremely tenacious when attached to these filamentous structures; larvae of $B$. amphitrite were rapidly lost. It is unclear if the detachment of $B$. amphitrite was related to any 
nematocyst discharge by the hydroids, as cyprids responded similarly on biofilms composed of filamentous algae and bacteria.

In many studies, resident communities are also negatively correlated with larval settlement as residents rapidly monopolize all available space (e.g. Connell 1972, Dayton 1975). Thus, free space is considered the limiting resource for many sessile marine invertebrates (e.g Sutherland 1974, Osman 1977, Sutherland \& Karlson 1977). In waters surrounding Beaufort, N.C., Sutherland \& Karlson (1977) found that most resident adults strongly inhibited the recruitment and growth of many species. They found that settlement of Balanus $\mathrm{sp}$. was significantly reduced on surfaces where hydrozoans, encrusting bryozoans, and upright and encrusting ascidians were present. Bugula neritina was, however, able to invade space in some cases, potentially because individuals required only a small amount of attachment space (Sutherland \& Karlson 1977). In our studies, larvae settled more frequently and explored more on fouled surfaces than on surfaces that were clean or had only a biological film (Table 1). Settlement of most ( $83 \%$ ) larvae of $B$. amphitrite occurred on 1 or 2 wk fouled surfaces and exclusively on 2 wk fouled surfaces (mean coverage: $85 \%$ ) for $B$. neritina. On surfaces with previously settled macro-invertebrates, flow modifications and a thickened boundary layer close to the surface may have greatly facilitated larval exploration.

\section{Summary}

All information on the larval ecology of biological fouling organisms, including barnacles and bryozoans, is useful in determining the most effective methods of preventing overgrowth on man-made structures submerged in our oceans, such as the hulls of ships. To date, only the importance of specific variables on settlement has been tested in moving water. With the use of video endoscopy, we are now able to make direct observations of larval exploration, comparing and contrasting the response of invertebrate larvae in flow to a number of potentially important settlement cues, including conspecifics, specific bacteria or bacterial products, and surface topography from the moment of contact up to the point when metamorphosis begins.

Acknowledgements. Dr B. MacDonald kindly loaned us his endoscope set-up for these experiments. Dr D. Rittschof and Dr J. Ramus, Director, provided us with laboratory space at the Duke University Marine Laboratory. Dr K. Reinsel, Dr M. Mcclary, G. Cannon and many others at DUML facilitated our undertaking this research. E. Bouvert wrote the AutoCad program. Dr P. Sacks assisted with the digitizing. Mr S. Gugg helped prepare the figures. Funding for this research was provided by Universite Laval and an NSERC grant to E.B.

\section{LITERATURE CITED}

Bingham BL, Walters LJ (1989) Solitary ascidians as predators of invertebrate larvae: evidence from. gut analyses and plankton samples. J Exp Mar Biol Ecol 131:147-159

Bourget $E$ (1988) Barnacle larval settlement: the perception of cues at different spatial scales. In: Chelazzi G, Vannini M (eds) Behavioral adaptations to intertidal life. Plenum, New York, p 153-172

Bourget E, Harvey M (1998) Spatial analysis of recruitment of marine invertebrates on arborescent substrata. Biofouling 12:45-55

Butman CA (1987) Larval settlement in soft-sediment invertebrates: the spatial scales of pattern explained by active habitat selection and the energy role of hydrodynamic processes. Oceanogr Mar Biol Annu Rev 25:113-165

Connell JH (1972) Community interactions on marine rocky intertidal shores. Annu Rev Ecol Syst 3:169-192

Cranfield HJ (1973) Observations on the behavior of the pediveliger of Ostrea edulis L. during attachment and cementing. Mar Biol 22:203-209

Crisp DJ (1961) Territorial behavior in barnacle settlement. J Exp Biol 38:429-446

Crisp DJ (1976) Settlement responses in marine organisms. In Newell RC (ed) Adaptations to environments: essays on the physiology of marine animals. Butterworths, London p 83-124

Crisp DJ (1984) Overview of research on marine invertebrate larvae, 1940-1980. In: Costlow JD, Tipper RC (eds) Marine biodeterioration: an interdisciplinary study. Naval Institute Press, Annapolis, MD, p 103-126

Crisp DJ (1990) Gregariousness and systematic affinity in some North Carolinian barnacles. Bull Mar Sci 47 $516-525$

Crisp DJ, Austen AP (1960) The action of copper in antifouling paints. Ann Appl Biol 48:787-799

Culliney JL (1969) Larval biology and recruitment of the shipworms Terredo navalis and Bankia gouldi in the Newport estuary, N.C. PhD dissertation, Duke University, Durham, NC

Dayton PK (1975) Experimental evaluation of ecological dominance in a rocky intertidal algal community. Ecol Monogr 45:137-159

Dicke M, Burrough PA (1988) Using fractal dimensions for characterizing turtuosity of animal trails. Physiol Entomol 13:393-398

Eckman JE, Savidge WB, Gross TF (1990) Relationship between duration of cyprid attachment and drag forces associated with detachment of Balanus amphitrite cyprids. Mar Biol 107:111-118

Erlandsson J, Kostylev V (1995) Trail following, speed and fractal dimension of movement in a marine prosobranch, Littorina littorea, during a mating and non-mating season. Mar Biol 122:87-94

Grosberg RK (1981) Competitive ability influences habitat choice in marine environments. Nature 290:700-702

Harvey $M_{r}$ Bourget $E$, Ingram RG (1995) Experimental evidence of passive accumulation of bivalve larvae on filamentous epibenthic structures. Limnol Oceanogr 40: 94-104

Hastings HM, Sugihara G (1993) Fractals: a user's guide for the natural sciences. Oxford University Press, New York

Havenhand JN, Svane I (1991) Roles of hydrodynamics and 
larval behavior in determining spatial aggregation in the tunicate Ciona intestinalis. Mar Ecol Prog Ser 68:271-276

Hills JM, Thomason JC (1996) A multi-scale analysis of settlement density and pattern dynamics of the barnacle Semıbalanus balanoides. Mar Ecol Prog Ser 138:103-115

Hills JM, Thomason JC (1998) The effect of scales of surface roughness on the settlement of barnacle (Semibalanus balanoides) cyprids. Biofouling 12:57-69

Hudon C, Bourget E, Legendre P (1983) An integrated study of the factors influencing the choice of the settling site of Balanus crenatus cyprid larvae. Can J Fish Aquat Sci 40:1186-1194

Johnson LE, Strathmann RR (1989) Settling barnacle larvae avoid substrata previously occupied by a mobile predator. J Exp Mar Biol Ecol 128:87-103

Keough M (1989) Variation in growth rate and reproduction of the bryozoan Bugula neritina. Biol Bull (Woods Hole) $177: 277-286$

Lehner PN (1979) Handbook of ethological methods. Garlans STPM Press, New York

Lemire M, Bourget E (1996) Substratum heterogeneity and complexity influence micro-habitat selection of Balanus sp. and Tubularia crocea larvae. Mar Ecol Prog Ser 135: $77-87$

LeTourneux F, Bourget E (1988) Importance of physical and biological settlement cues used at different spatial scales by larvae of Semibalanus balanoides. Mar Biol 97:57-66

Lynch WF (1947) The behavior and metamorphosis of the larvae of Bugula neritina: experimental modification of the length of the free-swimming period and responses of the larvae to light and gravity. Biol Bull (Woods Hole) 92:115-150

Maki JS, Rittschof D, Costlow JD, Mitchell R (1988) Inhibition of attachment of larval barnacles, Balanus amphitrite, by bacterial surface films. Mar Biol 97:199-206

Maki JS, Rittschof D, Schmidt AR, Snyder AG, Mitchell R (1989) Factors controlling attachment of bryozoan larvae: a comparison of bacterial films and unfilmed surfaces. Biol Bull (Woods Hole) 177:295-302

Meadows PS, Campbell JI (1972) Habitat selection by aquatic invertebrates. Adv Mar Biol 10:271-382

Mihm JW, Banta WC, Loeb GI (1981) Effects of adsorbed organic and primary fouling films on bryozoan settlement. J Exp Mar Biol Ecol 54:167-179

Miron G, Bourget E, Archambault P (1996a) Scale of observation and distribution of adult conspecifics: their influence in assessing passive and active settlement mechanisms in the barnacle Balanus crenatus (Brugière). J Exp Mar Biol Ecol 201:137-158

Miron G, Ward JE, MacDonald BA, Bourget E (1996b) Direct observations of particle kinematics within a scallop (Placopecten magellanicus) spat collector by means of video endoscopy. Aquaculture 147:71-92

Mullineaux LS, Butman CA (1991) Initial contact, exploration and attachment of barnacle (Balanus amphitrite) cyprids settling in flow. Mar Biol 110:93-103

Mullineaux LS, Garland ED (1993) Larval recruitment in response to manipulated field flows. Mar Biol 116:667-683

Nellis P, Bourget E (1996) Influence of physical and chemical factors on the settlement and recruitment of the hydroid Tubularia larynx: field and laboratory experiments. Mar Ecol Prog Ser 140:123-139

Osman RW (1977) The establishment and development of a marine epifaunal community. Ecol Monogr 47:37-63

Osman RW, Whitlatch RB, Zajac RN (1989) Effects of resident species on recruitment into a community: larval settlement versus post-settlement mortality in the oyster Crassostrea virginica. Mar Ecol Prog Ser 54:61-73
Pawlik JR (1992) Chemical ecology of the settlement of benthic marine invertebrates. Oceanogr Mar Biol Annu Rev 30:273-335

Pawlik JR, Butman CA, Starczak VR (1991) Hydrodynamic facilitation of gregarious settlement of a reef-building tube worm. Science 251:421-423

Rittschof D, Costlow JD (1989) Settlement determination of macroinvertebrate larval settlement. In: Klekowski RZ et al. (eds) Proc 21 st Eur Mar Biol Symp. Institute of Oceanology, Polish Academy of Sciences, Gdansk, p 155-163

Rittschof D, Branscomb ES, Costlow JD (1984) Settlement and behavior in relation to flow and surface in larval barnacles, Balanus amphitrite Darwin. J Exp Mar Biol Ecol 82:131-146

Rittschof D, Hooper IR, Costlow JD (1988) Settlement inhibition of marine invertebrate larvae: comparison of sensitivities of bryozoan and barnacle larvae. In: Costlow JD, Tipper RC (eds) Marine biodeterioration: an interdisciplinary study. Naval Institute Press, Annapolis, MD, p 599-608

Rittschof D, Clare AS, Gerhart DJ, Avelin M, Bonaventura J (1992) Barnacle in vitro assays for biologically active substances: toxicity and settlement inhibition assays using mass cultured Balanus amphitrite amphitrite Darwin. Biofouling $6: 115-122$

Roberts D, Rittschof D, Holm E, Schmidt AR (1991) Factors influencing initial larval settlement: temporal, spatial and surface molecular components. J Exp Mar Biol Ecol 150: 203-211

Ryland JS (1974) Behaviour, settlement and metamorphosis of bryozoan larvae: a review. Thalassia Jugosl 10:239-262

SAS Institute (1988) SAS language guide for personal computers, 6.03 edn. SAS Institute Inc, Cary, NC

Satuito CG, Shimizu K, Natoyama K, Yamazaki M, Fusetani N (1996) Age-related settlement success by cyprids of the barnacle Balanus amphitrite, with special reference to consumption of cyprid storage protein. Mar Biol 127 : $125-130$

Sutherland JP (1974) Multiple stable points in natural communities. Am Nat 108:859-873

Sutherland JP, Karlson RH (1977) Development and stability of the fouling community at Beaufort, North Carolina. Ecol Monogr 47:425-446

Walters LJ (1992a) Field settlement locations on subtidal marine hard substrata: is active larval exploration involved? Limnol Oceanogr 37:1101-1107

Walters LJ (1992b) Post-settlement success of the arborescent bryozoan Bugula neritina (L.): the importance of structural complexity. J Exp Mar Biol Ecol 164:55-71

Walters LJ, Wethey DS (1996) Settlement and early postsettlement survival of sessile marine invertebrates on topographically complex surfaces: the importance of refuge dimensions and adult morphology. Mar Ecol Prog Ser 137:161-171

Walters LJ, Hadfield MG, Smith CM (1996) Waterborne chemical compounds in tropical macroalgae: positive and negative cues for larval settlement. Mar Biol 126:383-393

Walters LJ, Hadfield MC, del Karmen KA (1997) The importance of larval choice and hydrodynamics in creating aggregations of Hydroides elegans (Polychaeta: Serpulidae). Invertebr Biol 116:102-114

Ward JE, Beninger PG, MacDonald BA, Thompson RJ (1991) Direct observations of feeding structures and mechanisms in bivalve molluscs using endoscopic examination and video image analysis. Mar Biol 111:287-291

Wethey DS (1984) Spatial pattern of barnacle settlement: daily changes during the settlement season. J Mar Biol Assoc UK 64:687-698 
Wethey DS (1986) Ranking of settlement cues by barnacle larvae: influence of surface contour. Bull Mar Sci 39:393-400

Wisely B (1960) Observations on the settling behavior of larvae of the tubeworm Spirorbis borealis Daudin (Polychaeta). Aust J Mar Freshw Res 11:55-72

Woollacott RM (1984) Environmental factors in bryozoan settlement. In: Costlow JD. Tipper RC (eds) Marine biodeterioration: an interdisciplinary study. Naval Institute Press, Annapolis, MD, p 149-154

Woollacott RM, Zimmer RL (1971) Attachment and metamor-

Editorial responsibility: Otto Kinne (Editor),

Oldendorf/Luhe, Germany phosis of the cheilostome bryozoan Bugula neritina (Linne). J Morphol 134:351-382

Yule AB, Walker $\mathrm{G}(1984)$ The temporary adhesion of barnacle cyprids: effects of diffenng surface characteristics. J Mar Biol Assoc UK 64:429-439

Yule AB, Walker G (1985) Settlement of Balanus balanoides: the effect of cyprid antennular secretion. J Mar Biol Assoc UK 65:707-712

Zar JH (1984) Biostatistical analysis. Prentice Hall Inc, Englewood Cliffs, NJ

Submitted: June 18, 1998, Accepted: December 23, 1998 Proofs received from author(s): May 18, 1999 